\author{
Available online at https://www.rjtl.org \\ Volume: 2, Issue: 2, 77-79, 2021 \\ ISSN: 2708-3632 \\ DOI: https://doi.org/10.46590/rjtl.2021.020201
}

\title{
Isolation of Sludge Protein from Skin Fleshing Wastes by Alkaline Hydrolysis and Determining its Effects as a Fertilizer on Growth of Some Nursery Plants: A Step Towards Tanneries Waste Utilization in Pakistan.
}

\author{
Beena Zehra*, Hafiz Rub Nawaz, Barkat Ali Solangi, Uzma Nadeem \\ Leather Research Centre, PCSIR, D-102, South Avenue, SITE, Karachi, Pakistan.
}

Paper History

Received: March 2021

Accepted: April 2021

Published: May 2021

Corresponding Author

Beena Zehra

zehrabeena@yahoo.com
Abstract: During Leather Processing, Skin Fleshing Wastes (SFW) are usually disposed of in an open area which creates toxic hazards. In this study, $(S F W)$ from tanneries have been hydrolyzed using two alkalis Potassium hydroxide ( $2 \mathrm{~g} / 100 \mathrm{~g}$ of $S F W$ ) and Sodium hydroxide ( $4 \mathrm{~g} / 100 \mathrm{~g}$ of $S F W$ ) with a sufficient amount of water at $230^{\circ} \mathrm{F}$ in Autoclave for two hours. Three resultant fractions fats and oil (approximately $240 \mathrm{~g} \mathrm{Kg}^{-1}$ ), protein (approximately $554 \mathrm{~g} \mathrm{Kg}^{-1}$ ) and sludge containing a high amount of ashes (approximately $900 \mathrm{~g} \mathrm{Kg}^{-1}$ ) were successfully isolated respectively. The yield of fractions was calculated on the wet weight of $S F W$ used after the removal of lime using ammonium sulphate. In this study, the isolated third fraction Fleshing Sludge $(F S)$ from the hydrolyzed fleshing wastes used fertilizer on the six different plants on growth commonly named Ghobi, Cran Dola, Patunia, Placus, Dentist and Dalia. The observations were taken during 30 days of incubation, at the usual temperature. The application of $F S$ in plants observed that growth was enhanced in significant proportion as compare to reference plants supplemented with commercial fertilizer except in the Ghobi sample PS1 which shows some phytotoxicity confirmed by leaf yellowing. The results revealed that the applied sludge has no adverse effect on the growth of other experimental plants. Results were taken by measuring plants according to standard methods.

Keywords: Hydrolysis, Skin Fleshing Wastes, Sludge

Citation: Beena Zehra, Hafiz Rub Nawaz, Barkat Ali Solangi, Uzma Nadeem., "Isolation of Sludge Protein from Skin Fleshing Wastes by Alkaline Hydrolysis and Determining its Effects as a Fertilizer on Growth of Some Nursery Plants: A Step Towards Tanneries Waste Utilization in Pakistan.” Research Journal of Textile and Leather, 2(2), 77-79, 2021.

\section{INTRODUCTION}

Skin fleshing wastes are one of the major solid wastes, generated during pre-tanning operations of leather processing. These contain the highest protein content (50-60\%) and collagen (3-5\%) content which is currently being wasted, thus creating the solid waste disposal problem in tanneries [1-2]. The method commonly used for this waste disposal (landfill or incineration) required high operational expenses [3]. Due to the high costs of industrial fertilizer in certain tropical areas, alternative solutions to increase the nitrogen availability for the crop have to be introduced [4]. The collagen extracted from wastes of tanneries has shown to be a good alternative source of nitrogen for the growth of elephant grass - Pennisetum purpureum Schumach. cv. Napier. The application of collagen supplied, similarly to fertilization with mineral nitrogen in the elephant grass plants has been reported [4].
The application of industrial organic wastes to agricultural land has received important attention in recent years, as it efficiently disposes of waste products while recycling costly nutrients into the soilplant environment [5-6]. Some studies have been carried out on different types of solid and liquid leather tanning wastes which have proven to be efficient when used as fertilizers and soil agents and confirmed the efficiency [7]. Chrome tanned solid wastes from tanneries have been used as a potential fertilizer after the chromium extraction, and modification with mineral $\mathrm{P}$ and $\mathrm{K}$ adsorption used as a N-Collagen PK fertilizer shown promising agronomic results [8]. Therefore, this study was aimed to utilize leather solid waste which is a current problem-solving issue for world tanneries. Thus, the main research objective was to investigate the effects of sludge Protein from skin fleshing wastes utilization as a useful fertilizer product on different plants without any prior modification which is a 
novelty of this work because this FS has not utilized as a fertilizer in previous studies.

\section{MATERIAL AND METHODS}

Skin Fleshing wastes were collected from tanneries of Leather Research Centre and Shafi Tanneries, SITE, Karachi from Sheep and Goatskin processing. Chemicals for the de-liming and hydrolysis were commercial grade. Autoclave from Steroclave,USA was used. Plants for the study were purchased from the local nursery of Karachi. All Plants were in small previously grown size in small size pots. These plants had a basal outlet for exhausting the excess amount of water thus minimizing the accumulation of salts in the soil profile. Each species was purchased in two same sizes. All pairs of purchased plants were measured followed by American Standard For Nursery Stock (1996), which has been developed by the American Nursery \& Landscape Association (ANLA) for use in the nursery industry.

\subsection{Experimental Procedure}

\subsubsection{Preparation of Fertilizer}

In the first step, Skin fleshing wastes comprising skin collagen with a large amount of water were washed twice with water. Then these SFW were delimed using 2\% ammonium Sulphate with a sufficient amount of water stirring for 30 minutes in a large tub. The $\mathrm{pH}$ of the delimed fleshing was 8.0 after the complete deliming process. These delimed SFW were hydrolyzed in an autoclave for 2 hours at $230^{\circ} \mathrm{F}$. After that hydrolyzate was cooled at room temperature. Then kept in the refrigerator for 24 hours. Three fractions were isolated from the hydrolyzate.

The first fraction was fats and oils, the second was collagen protein and the third was a dark-coloured sludge. Separated Fats and Protein have been used for the other experimental investigations while FS was selected to used fertilizer in this study. These recovered all three fractions were kept separately. The next day, FS was taken out from the refrigerator and diluted with water then sieved with a fine cloth to remove any large particles. Then the solution was homogenized with a high-speed stirrer for continuous 30 minutes. The $\mathrm{pH}$ of the solution was 6.5-7.0 which was suitable for the application. This was used as a fertilizer without any chemical modification.

\subsubsection{Application of fertilizer}

Prepared fertilizer material was applied at different dosages 10/100, 20/100, 30/100, 40,/100 50/100,60/100 gram of soil (vol/wt) into each plant and marked as PS:1, PS:2, PS:3, PS:4, PS:5, PS:6, PS:7 whereas reference plants were marked as PR:1,
PR:2, PR:3, PR:4, PR:5, PR:6, PR:7. The dosage of the prepared fertilizer was added into each sample by thoroughly mixing it into each plant. Each dose was given at 11:00 am in sunny weather. All plants were kept in an open atmosphere.

\section{RESULTS AND DISCUSSION}

Due to the adverse effects of synthetic fertilizer products in Agriculture, bio-based fertilizers from natural sources are much demanded at various places. Therefore, delimed fleshing wastes were hydrolyzed with potassium hydroxide and sodium hydroxide due to achieve high-quality hydrolysate with maximum amounts of salts to be useful for the plants. The final product contained $80-85 \%$ solid content having salts with a balanced ratio of amino acids. It was diluted with $(50 \%)$ water and then apply as discussed in material and methods. The observations were taken after the interval of each 3 days. The growth was recorded in terms of increasing the leaves area, increase in shoots and number of branches. While reproductive parameter in terms of flowers was also observed. Sample (PS:1) when compare with the PR1 shown slightly phytotoxicity after the growth which was revealed by the leaf yellowing which confirmed that the plant hardly tolerated the applied dose. This nursery plant was more sensitive as compared with other species of the nursery plant under this study. While samples (PS:2 \& PS:3) shown the favourable effect of applied dose confirmed from the flowering as compare with samples( PR:2 \& PR:3). More flowers were found in the sample (PS:2). Moreover, some yellow leaves were found in the sample (PR:2). Sample ( PS:4 \& PS:5) were also shown good results of tolerance and no leaf yellowing was observed. Samples (PS:6 and PS:7) were also shown good results as compared to their reference in which some yellowing in the leaves was observed.

These results were due to the supply of nitrogen through amino acids since several plants can absorb amino acids and sometimes these amino acids are a better source for providing nitrogen as compare to ammonia or nitrate. The higher supplies of Nitrogen to the plants using leather residues applied to the soil have been studied earlier by some authors [9-12]. The capability of individual amino acids to be good fertilizer in plant production is dependent upon two factors that the source is available cheaply and the second is the quick rate of absorption. Besides this, the fertilizer effect of FS was also excellent due to the utilization of salts (Potassium hydroxide and Sodium hydroxide) in the hydrolysis these salts have shown supplemental action. 


\section{CONCLUSION}

Fertilizer is the major factor affecting plant growth and quality. It was revealed that the high growth rate was determined at the dosage of 40-60g of FS /100 gram of soil weight since Nitrogen from the fleshing wastes can play a vital role in the growth of plants. However, it should be modified with other nutrients to enhance the efficiency of FS. It may be possible that it affects different rates on different species of plants because uptake of amino acids is dependent on changing plant species. The proposed approach for the utilization of waste sludge/residue from fleshing wastes as a fertilizer in Pakistan is a balancing step to avoiding landfill through the establishment of environmentally friendly and less expensive technology for tanneries.

\section{ACKNOWLEDGEMENTS}

The authors are very thankful to Mr.Raja Asad and Mr.Shams-UZ-Zaman (lab Technicians) for their assistance in our work.

\section{REFERENCES}

[1]. Ravindran, B., Dinesh, S.L., John Kennedy, L., Sekaran, G., vermicomposting of solid waste generated from leather industries using epigeic earthworm Eisenia foetida. Applied Biochemistry and Biotechnology 151 (2-3), 2008, 480-488.

[2]. Ganesh Kumar, A., Swarnalatha, S., Sairam, B., Sekaran, G., Production of alkaline protease by Pseudomonas aeruginosa using proteinaceous solid waste generated from leather manufacturing industries. Bioresource Technology 99(6), 2008, 1939-1944.

[3]. R. Aravindhan, B. Madhan, J.R. Rao, B.U. Nair, T. Ramasami, Bioaccumulation of chromium from tannery wastewater: an approach for chrome recovery and reuse, Environ. Sci. Technol. 38 (2004) 300-306.

[4]. D.Q.L. Oliveira, K.T.G. Carvalho, A.R.R. Bastos, L.C.A. Oliveira, J.J.G.M.M. Marques,R.S.M.P. Nascimento, Utilizac, ão de resíduos da indústria de courocomo fonte nitrogenada para o capim elefante, R. Bras. Ci. Solo. 32 (2008) 417-424.

[5]. Antolin, M.C., Pascual, I., Garcia, C., Polo, A., Sanchez-Diaz, M. Growth, yield and solute content of barleyin soils treated with sewage sludge under semiarid Mediterranean conditions. Field Crops Res. 94, (2005) 224.

[6]. Karlen, D.L., Wright, R.J., Kemper, W.O. Agriculture utilization of urban and industrial byproducts. ASA Spec.Publ. n. 58. ASA, CSSA and SSSA, Madison, WI, USA,(1995) 295.
[7]. E.E. Konrad, D.D. Castilhos, Soil chemical changes and corn growth as affected by the addition of tannery sludges, R. Bras. Ci. Solo 26 (2002) 257-265.

[8]. Francisco G.E. Nogueira, Nayara T. do Prado, Luiz C.A. Oliveira, Ana R.R. Bastos, João H. Lopes, Janice G. de Carvalho, Incorporation of mineral phosphorus and potassium on leather waste (collagen): A new NcollagenPK-fertilizer with slow liberation, Journal of Hazardous Materials 176 (2010) 374-380.

[9]. K. Kolomaznik, M. Adamek, I. Andel, M. Uhlirova, Leather waste - potential threat to human health, and a new technology of its treatment, J. Hazard. Mater.160 (2008) 514520.

[10].S.B.C. Pergher, L.C.A. Oliveira, A. Smaniotto, D.I. Petkowicz, Magnetic zeolites for removal of metals in water, Quim. Nova 28 (2005) 751755.

[11].S.T. Teixeira, W.J. Melo, E.T. Silva, Plants nutrients in a degraded soil treated with water treatment sludge and cultivated with grasses and leguminous plants, Soil Biol. Biochem. $\quad 39$ (2007) 1348-1354.

[12].A.S. Ferreira, F.A.O. Camargo, M.J. Tedesco, C.A. Bissani, Effects of tannery and coal mining residues on chemical and biological soil properties and corn and soybean yields, R. Bras. Ci. Solo 27 (2003) 755-763. 